\title{
Geologia Croatica
Dinaride evaporite mélange: Diagenesis of the Kosovo polje evaporites
}

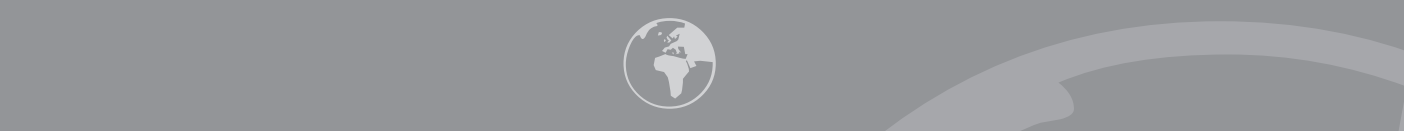

Anita Kulušić and Sibila Borojević Šoštarić

Faculty of Mining, Geology and Petroleum Engineering, University of Zagreb, Pierottijeva 6,

HR-10000 Zagreb; (sibila.borojevic-sostaric@rgn.hr; phone: +385-1-4605 800; fax: +385-1-4836 057 )

doi: $10.4154 / \mathrm{gc} .2014 .05$

\begin{abstract}
The Dinaride evaporite mélange is composed of evaporites and associated sedimentary and magmatic formations of Permian to Triassic age and floored by the various Adriatic carbonate platform units. The tectonic history of the Dinaridic evaporite mélange is related to long term burial and Palaeogene to Neogene exhumation processes. Evaporite rocks of the Kosovo polje deposits are associated with carbonates, clastic and minor albitized, subvolcanic, neutral to basic rocks. They are capped by a clayey Quaternary cover of variable thickness, and a several metres thick cavernous carbonate breccia-rauhwacke. Evaporite rocks show two distinct facies: laminated evaporite-carbonate, composed of evaporite and dolomicrite ( \pm organic matter, pyrite, halite) intercalations, and evaporite-carbonate breccia, composed of fragments of laminated evaporites, carbonate and siltite, cemented by massive gypsum \pm sulfur, occurring at the shallower levels and related to the emplacement. The Quaternary cover is composed of $47-88 \%$ clayey material, comprising illite, kaolinite and most likely vermiculite, $9-49 \%$ carbonate and $3-4 \%$ evaporite minerals. The thickness of the evaporite rehydration zone correlates negatively with the thickness of the overlying Quaternary cover and with the amount of clayey material within it. Rauhwacke are composed of partly dedolomitized dolostone and leached gypsum fragments, cemented with late stage calcite. Diagenetic processes are related to early diagenesis and the burial phase began with the formation of diagenetic halite from an oversaturated subsurface or surface (lagoon) brine, and was followed by the biochemical reduction of evaporite sulphate to sulfide and formation of pyrite within organic-rich carbonate laminae. These processes triggered early dolomitization (in a shallow burial realm), and the formation of idiomorphic planar-e type of dolomite crystals at temperatures below $50-60^{\circ} \mathrm{C}$. Planar dolomite suppressed diagenetic halite. With an increase in burial depth, gypsum dehydrates to anhydrite and when temperatures exceed $\sim 50{ }^{\circ} \mathrm{C}$, precipitation of fine grained non-planar-a type of dolomite began. Halite molds are partly replaced with non-planar-a type of dolomite. During regional uplift and exhumation, anhydrite rehydrated to gypsum under the influence of low-temperature undersaturated fluid (meteoric water), whereas hydrogen-sulfide oxidized to elementary sulfur, observed as cement in the evaporite-carbonate breccia. Rauhwacke at the uppermost part of the deposit are formed by severe tectonic movements associated with the gypsum-driven dedolomitization process.
\end{abstract}

Keywords: evaporite mélange, burial, emplacement, diagenesis, gypsum-anhydrite transition zone, Kosovo polje evaporites, Dinarides

\section{INTRODUCTION}

During the collisional phase of the orogenic belts, evaporite layers, due to the low shear resistance of the associated minerals, usually control the location of major detachment zones acting as the lubricant for large-scale displacements (e.g. DAVIS \& ENGELDER, 1985). In the area of the Northern Calcareous Alps (SPÖTL \& HASENHÜTTL, 1998; SCHROLL \& NEUBAUER, 2013), and Dinarides (HERAK, 1973) evap- orites appear as a tectonic mélange in front of the large thrust surfaces. Evaporite mélanges of the Northern Calcareous Alps and Dinarides are commonly associated with various types of sedimentary, magmatic and metamorphic rocks (SPÖTL \& HASENHÜTTL, 1998; SCHROLL \& NEUBAUER, 2013; GRANDIĆ et al., 2004; BOROJEVIĆ-ŠOŠTARIĆ \& NEUBAUER, 2012). They often preserve various fabrics formed during diagenesis and the final emplacement of the evaporites along the thrust surfaces. 
A Dinaridic evaporite mélange is located in front of the Palaeogene to Neogene large trusts fronts (Fig. 1). This mélange is mainly composed of gypsum and anhydrite associated with various types of sedimentary to magmatic rocks. The age of the evaporites is considered to be Permian to Triassic by most of the authors (HERAK, 1973; ŠUŠNJARA et al., 1992; SIFTAR, 1986). The tectonic history of the Dinaridic evaporite mélange is related to long term burial and Palaeogene to Neogene exhumation processes. These processes were followed by various types of diagenetic reactions and alteration, transformations and volume changes (WARREN, 2006 and references therein), including formation of secondary evaporites, dehydratation to rehydratation reactions (gypsum - anhydrite transition), dolomitization to dedolomitization, cementation and precipitation of authigenic minerals such as clays or quartz. All of the listed reactions are highly dependent on temperature, pressure, pore-water geochemistry, water-table level, mineralogical composition and thickness of the overlying deposits as well as the regional uplift rate.

In this paper we present a set of mineralogical, petrographical and chemical data from selected drill-cores of the Kosovo polje gypsum quarry, Knin, Croatia. The purpose of this study was to examine the types and intensities of the diagenetic changes related to the emplacement of the Kosovo polje evaporite mélange.

\section{GEOLOGICAL SETTING}

\subsection{Dinaride evaporite mélange}

The Adriatic Carbonate platform represents the most external sector of the Dinarides, a southwest-vergent Cenozoic orogen to the northeast of the Adriatic Sea (Fig. 1). It is composed of a thick carbonate succession (at some places $>8000 \mathrm{~m}$ ) of Middle Permian to Eocene age (VLAHOVIĆ et al., 2005; PAMIĆ et al., 1998 and references therein). Onset of deposition of siliciclastic, carbonate and evaporite deposits began with an epeiric type platform, detached from the Gondwana supercontinent (i.e. the South Tethyan Megaplatform; sensu VLAHOVIĆ et al., 2005), and was followed by the Late Permian to Early Triassic large-scale tectonic reorganization and intra-plate magmatism (PAMIĆ, 1984). The Uppermost Triassic early to late diagenetic Hauptdolomit or Dolomia Principale represents the latest sequence deposited on the Megaplatform, prior to its Early Jurassic disintegration. Carbonate deposition beginning in the Middle Jurassic, already belongs to the Adriatic carbonate platform sensu stricto.

Based on the geological, petrological, palaeontological, structural and isotope data extracted from previous literature (ŠĆAVNIČAR, 1973; PAMIĆ, 1984; ŠUŠNJARA et al., 1992; TIŠLJAR, 1992; GRANDIĆ et al., 2004; VLAHOVIĆ et al., 2005; PAMIĆ \& BALEN, 2005; GELETTI et al., 2008; KORBAR, 2009) we can summarize the following:

(1) Evaporites are located in front of the Palaeogene to Neogene thrust fronts; onshore as an evaporitic mélange (Croatia and Bosnia and Herzegovina), and offshore as diapiric structures in the central and southern part of the Adriatic Sea (sensu GRANDIĆ et al., 2004; GELETTI et al., 2008).
(2) The onshore evaporitic mélange is composed of sabkha (TIŠLJAR, 1992) type evaporites (gypsum and anhydrite); various types of carbonates (early diagenetic dolostone, lagoonal and intertidal limestone); clastic rocks (siltstone, sandstone and rarely conglomerate); and albitized subvolcanic neutral to basic rocks (PAMIĆ, 1984; ŠUŠNJARA et al., 1992; TIŠLJAR, 1992; PAMIĆ \& BALEN, 2005). Offshore Adriatic diapirs are composed of rock-salt and anhydrite (MATTAVELLI et al., 1991; BABIĆ, 1990; SPAIĆ, 2012) and neutral to basic subvolcanic to volcanic rocks (PALINKAŠ et al., 2010).

(3) Onshore evaporites are of Late Permian to early Triassic age, based on palynological analysis ( ̌́UŠNJARA et al., 1992) and sulphur isotope analysis of gypsum and anhydrite (ŠIFTAR, 1986). Recently published data imply that some of the offshore evaporites are of similar age o the onshore evaporites (PALINKAŠ et al., 2010). However, there are different opinions, claiming Late Triassic, Middle-Upper Jurassic or Upper Jurassic to Cretaceous ages for some of the offshore and drillcore evaporites (e.g. Ravni Kotari; KORBAR, 2009; KORBAR et al., 2009 and references therein). Detail palynological analysis (BELAK et al., 2005; BELAK \& KOCH 2009) of the offshore Vis evaporites gave an assemblage of Ladinian to Carnian age. Ar/Ar analyses obtained from the separated plagioclase from nearby Jabuka and Brusnik insoles gave ages of $227 \pm 5$ and $219 \pm 3 \mathrm{Ma}$ respectively (DE MIN et al., 2009).

Several lines of evidence support the argument that Permian to Triassic deposits exposed on the Adriatic carbonate platform represents a tectonic-emplaced evaporite mélange of the Dinarides:

(1) Permian to Triassic deposits, composed of evaporites and associated sedimentary and magmatic blocks (tens of metres to hundreds of metres in size), represents a distinct thrust-related formation resting on the younger Adriatic carbonate platform units, in front of the Palaeogene-Neogene thrusts (Figs. 1, 2).

(2) Permian to Triassic deposits are exclusively covered by Rauchwacke originated by evaporite leaching (TIŠLJAR, 1992) and younger Quaternary deposits.

(3) It is unclear whether gypsum to anhydrite represents an exclusive matrix of the Dinaride evaporite mélange since immediate contacts between the Permian to Triassic rocks and the surrounding evaporites are rarely exposed (Sinj location, South Adriatic islands; BARIĆ, 1969; GRANDIĆ et al., 2004).

(a) However, at some locations, pebbles and fragments of albitzed magmatic rocks occur embedded within the evaporites (BARIĆ, 1969) implying their common origin.

(b) Magmatic rocks usually form morphologically prominent highs within the evaporite valleys (ŠUŠNJARA et al., 1992) leading to the conclusion that evaporites previously embedding the magmatics, vanished through time. 


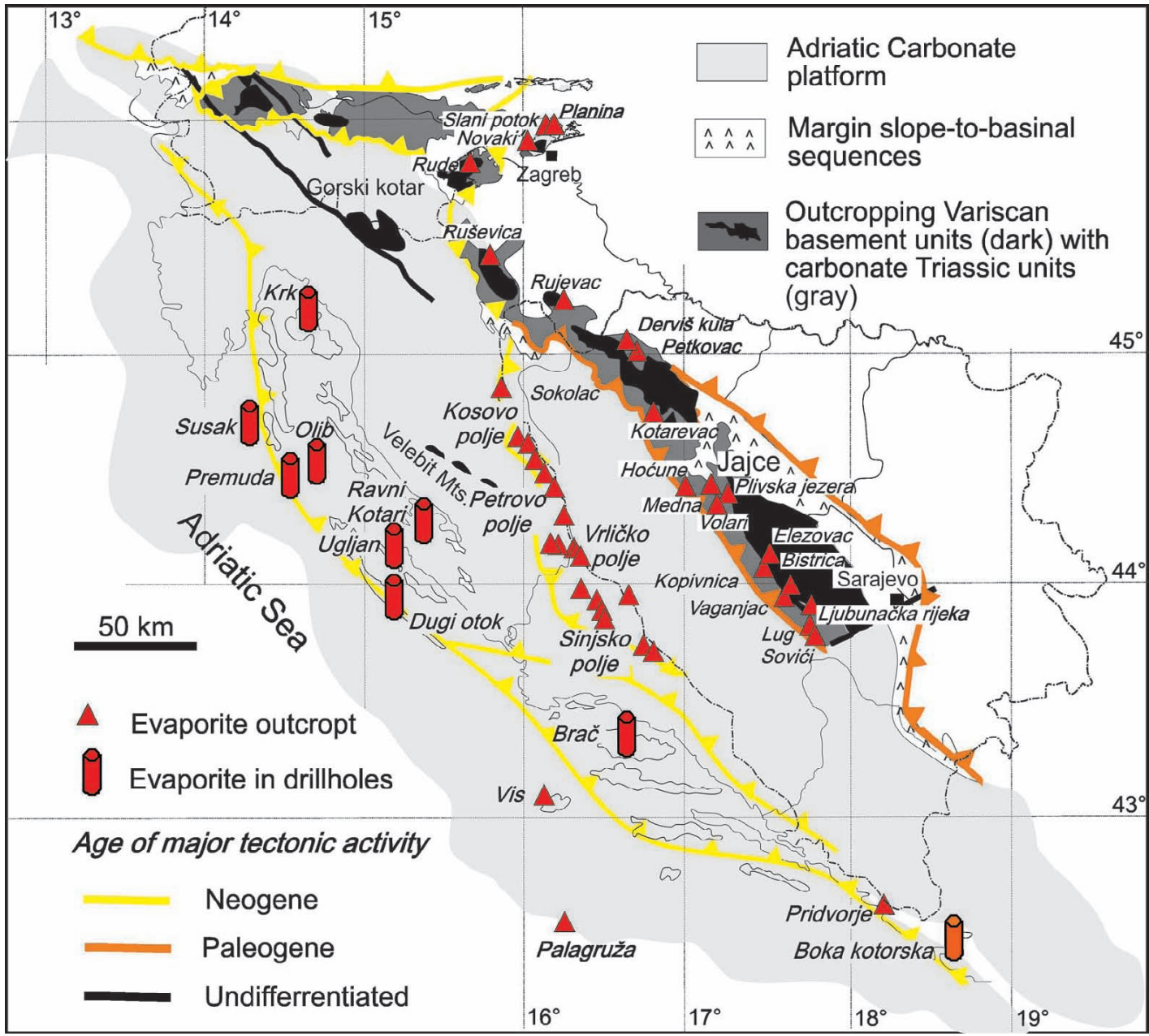

Figure 1: Simplified geological map of the Dinarides showing distribution of evaporites located in front of the Palaeogene to Neogene large thrust fronts (simplified after KORBAR, 2009; SCHMIDT et al., 2008; TOMLJENOVIĆ, 2002; GABRIĆ et al., 2002; TIŠLAR, 1992 and ŠUŠNJARA et al., 1992).

Therefore, we can summarise the following: a Dinaric evaporite mélange is composed of Permian to Triassic evaporites and associated sedimentary and magmatic blocks (tens of metres to hundreds of metres in size), sometimes embedded within evaporites and thrusted onto the younger Adriatic carbonate platform units.

Most of the Dinaride evaporite mélange outcrops are located within karst poljes and valleys such as: Vrličko, Kninsko, Petrovo and Drniš karst polje within the Lika and Dalmatia areas and neighbouring regions in SW Bosnia and Herzegovina (Fig 1). These outcrops are large, economically significant and under exploitation (> $1 \mathrm{Mt}$; GABRIĆ et al., 2002). They are composed of gypsum in the upper part and anhydrite in the lower part, and are covered by Rauhwacke and Quaternary sediments (mostly clay) of variable thickness. The amount of anhydrite increases with depth, and generally, within the investigated deposits, gypsum occurs within the uppermost $20-40 \mathrm{~m}$ (GABRIĆ et al., 2002). This is due to partial rehydration of anhydrite to gypsum under the influence of meteoric water related to regional uplift and erosion.

\subsection{Geology of the Kosovo polje}

Kosovo polje is a small size karst field $\left(33 \mathrm{~km}^{2}\right)$ located in the central part of the Adriatic carbonate platform at an elevation of $300-350 \mathrm{~m}$ above sea level. It is surrounded by up to 1000 m-high hills, composed of early Triassic to Late Cretaceous limestone and dolostone, intercalated with clastics at some locations. About $30 \%$ of the total Kosovo polje surface is represented by Late Permian to Early Triassic evaporite mélange units (Figs. 2a, b). The evaporite mélange is overlain by Quaternary deposits and Rauhwacke of variable thickness. The Kosovo polje is bounded by thrust faults (HERAK, 1973) covered by overstep carbonate-clastic flysch sequences; the Promina deposits (TIŠLJAR, 1992; ŠUŠNJARA et al.1992). During the exploitation of the evaporite (at Mali Kukor, Veliki Kukor, Sijećko, Bulavato open pits) numerous subvertical to vertical faults were discovered (LUKŠIĆ et al., 2005ํ), illustrating strong tectonic activity related to the emplacement of the evaporite complex (sensu HERAK, 1986).

Extended drilling in this area resulted in over 100 cores with a maximum length of $\sim 70 \mathrm{~m}$ (Fig. $2 \mathrm{~b}$ ). From twelve

${ }^{1}$ LUKŠIĆ, B., CRNOGAJ, S., DEDIĆ, Ž. \& JURIĆ, A. (2005): Report on gypsum reserves of the Novo Bulatovo and Pusto groblje quarries of the Kosovo exploitation field.- Unpublished report, Croatian Geological Survey, Zagreb. 


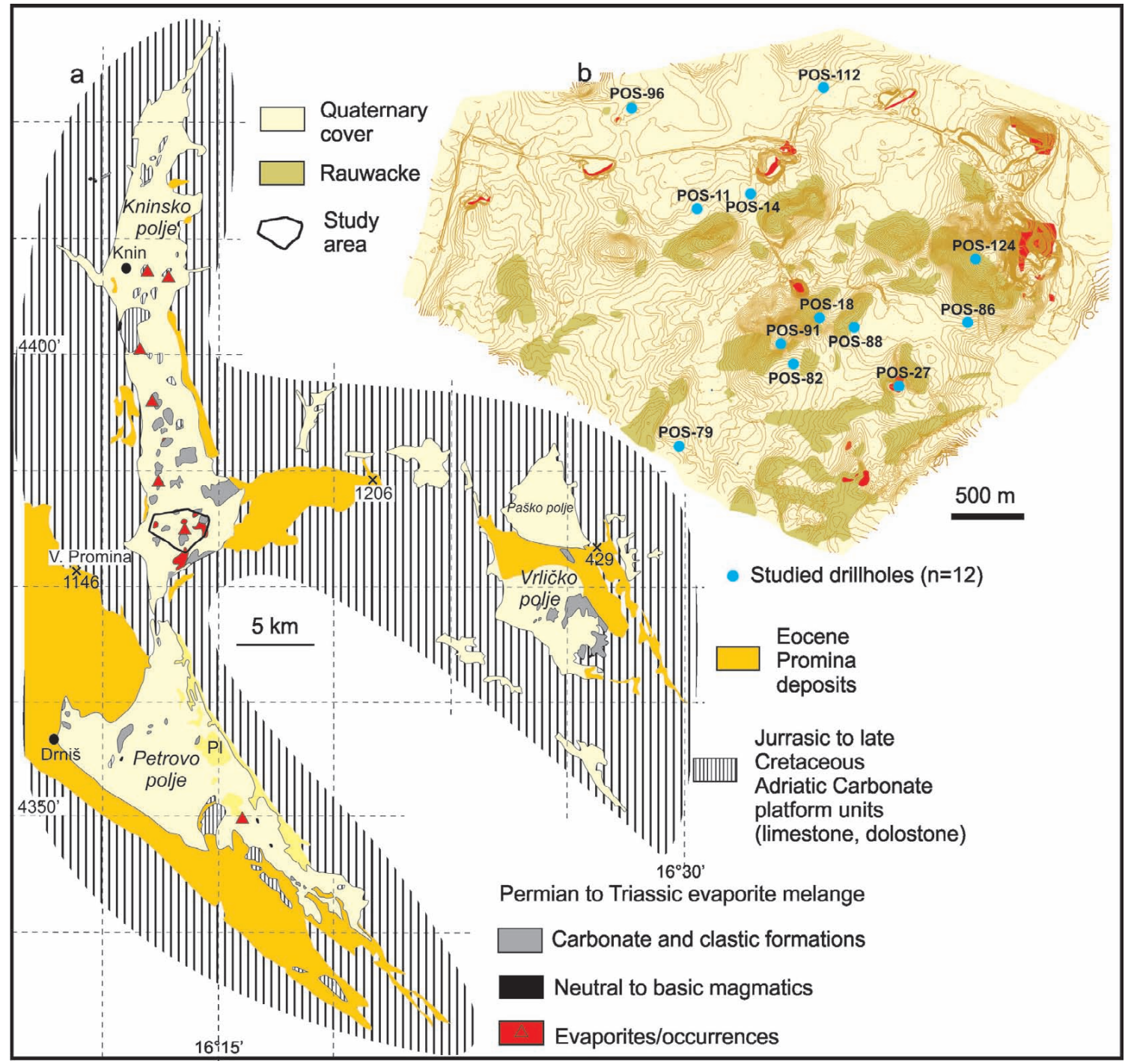

Figure 2: (a) Simplified geological map of the Kosovo polje (after IVANOVIĆ et al., 1967-1972; GRIMANI et al., 1962-1966; PAPEŠ et al., 1968-1980) and (b) Lithostratigraphic map of the Kosovo karst polje with the positions of the analyzed drill-cores (with permission of the Knauf company).

representative drill cores, over 70 hand specimens were selected for mineralogical, petrographical and XRD analyses. All of the studied cores display the following successions: (i) Quaternary clays, (ii) rauhwacke (not always present) (iii) gypsum zone, (iv) gypsum-anhydrite transition zone and (v) anhydrite zone. Geological logs with sample locations are presented in Fig. 3.

The layey Quaternary cover is composed of millimetre to centimetre sized carbonate and evaporite fragments within a predominantly clayey matrix (Fig. 4a). Cover sediments display variable thickness, from 3.5 to 34 metres, which correlates with the depth of gypsum and the gypsum-anhydrite transition zone. Within drill-cores with a thick cover $(20-30 \mathrm{~m})$, the gypsum zone is only several metres-thick and increases to $>50 \mathrm{~m}$ with decreasing thickness of the cover deposits. At some locations, the immediate contact with the underlying evaporite is hidden by a $<1-6 \mathrm{~m}$ thick layer of cavernous and sometimes clayey breccia, e.g. rauhwacke. The breccias are composed of various-sized fragments of limestone, dolostone (sometimes dedolomitized) and partially leached gypsum, ce- mented with calcite and are occasionally cavernous (Figs. $4 \mathrm{~b}, \mathrm{c})$. Their origin is related to the leaching of the tectonicallydisrupted evaporites and most likely driven by percolating meteoric water (TIŠLJAR, 1992). Evaporites show basically two types of macro-facies:

(i) laminated evaporite-carbonate facies, composed of millimetre to centimetre gypsum/anhydrite laminae intercalated with dolomite/dolomicrite \pm organic matter \pm siltite, the dolostone member is usually several times thinner than the sulfate one (Figs. $5 \mathrm{a}, \mathrm{b})$; and

(ii) evaporite-carbonate breccia facies, composed of millimetre to decametre-sized fragments of laminated sulfate, carbonate and siltite cemented by massive gypsum and occasionally sulfur, most likely originating during emplacement (Figs. 5c,d; already recognized by TIŠLJAR, 1992). An evaporite-carbonate breccia with below $5 \mathrm{vol} \%$ of carbonate, prevails in the uppermost levels of the evaporite succession, followed by the laminated facies down dip. 

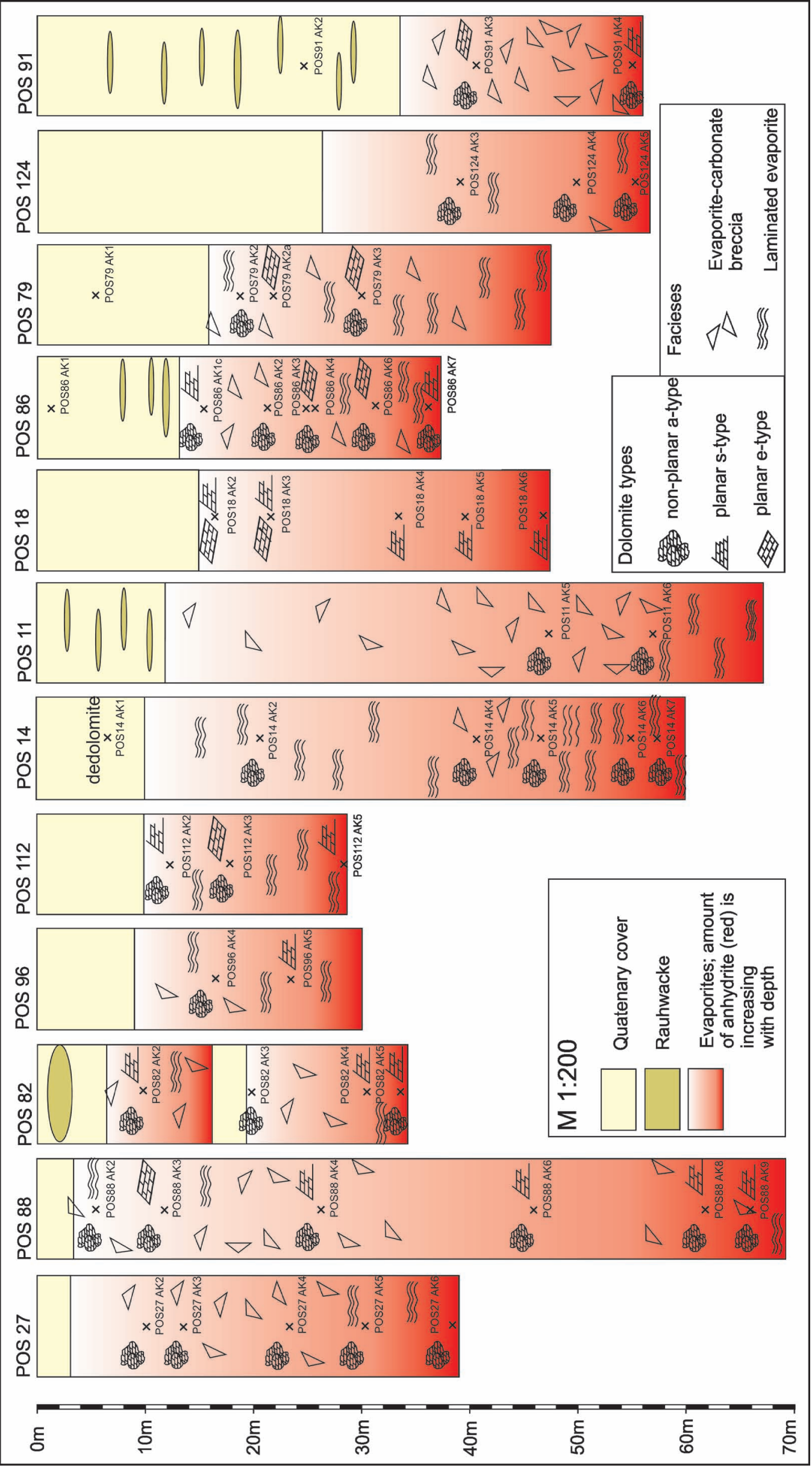
Table 1: Petrography of the analyzed samples of the Kosovo carst polje with marked analysis types.

\begin{tabular}{|c|c|c|c|c|}
\hline \multicolumn{5}{|c|}{$\begin{array}{l}\text { Kosovo polje carst polje } \\
\text { Quaternary cover }\end{array}$} \\
\hline POS-14 AK1 & $6.00-6.50$ & Gy, Cal, Anhy, Q \pm Om & & + \\
\hline POS-79 AK1 & $6.00-6.50$ & Gy, Cal, Q \pm Ms & & + \\
\hline POS-86 AK1 & $1.40-1.70$ & $\mathrm{~Gy}, \mathrm{Cal}, \mathrm{Ms} \pm \mathrm{Q}, \mathrm{Om}$ & & + \\
\hline POS-88 AK1 & $1.00-2.00$ & Gy, Cal, Q \pm Ms & & + \\
\hline \multicolumn{5}{|l|}{ Rauwacke } \\
\hline POS-91 AK2 & $25.00-25.50$ & Gy, Cal, Do \pm Anhy & + & \\
\hline \multicolumn{5}{|l|}{ Evaporites } \\
\hline POS-11 AK5 & $48.00-48.40$ & Gy, Anhy, Do \pm Om, Opq & \multirow{27}{*}{$\begin{array}{l}+ \\
+ \\
+\end{array}$} & \\
\hline POS-11 AK6 & $57.90-58.50$ & Anhy, Gy, Do $\pm P y, O m$ & & \\
\hline POS-14 AK2 & $21.30-21.60$ & Gy, Do $\pm A n h y, O p q, O m$ & & \\
\hline POS-14 AK4 & $41.55-41.75$ & Gy, Anhy, Do \pm Om, Opq & & \\
\hline POS-14 AK5 & $46.70-46.90$ & Anhy, Do, Gy \pm Om, Opq & & \\
\hline POS-14 AK6 & $55.50-56.00$ & Anhy, Do, Gy \pm Om & & \\
\hline POS-14 AK7 & $57.30-57.60$ & Anhy, Do, Gy \pm Opq & & \\
\hline POS-18 AK2 & $15.50-16.10$ & Gy, Do \pm Anhy $\pm O m, O p q$ & & \\
\hline POS-18 AK3 & $21.00-21.30$ & Gy, Do \pm Anhy, Om, Q & & \\
\hline POS-18 AK4 & $33.20-33.60$ & Anhy, Gy, Do & & \\
\hline POS-18 AK5 & $39.60-39.90$ & Anhy, Do \pm Opq & & \\
\hline POS-18 AK6 & $46.90-47.35$ & Anhy, Gy, Do \pm Opq & & \\
\hline POS-27 AK2 & $10.20-10.50$ & Gy, Do $\pm A, O p q, O m$ & & \\
\hline POS-27 AK3 & $13.45-13.95$ & Anhy, Do, Gy \pm Opq, Om & & \\
\hline POS-27 AK4 & $23.40-23.90$ & Do, Anhy, Gy \pm Opq, Om & & \\
\hline POS-27 AK5 & $30.30-30.60$ & Anhy, Do, Gy \pm Opq, Om & & \\
\hline POS-27 AK6 & $38.55-38.90$ & Do, Anhy, Gy \pm Opq, Om & & \\
\hline POS-79 AK2 & $19.00-19.40$ & Gy, Do, OmะAnhy,Opq & & \\
\hline POS-79 AK2a & $21.80-23.00$ & Gy, Do & & \\
\hline POS-79 AK3 & $30.30-30.60$ & Gy, Do \pm Anhy & & \\
\hline POS-79 AK4 & $38.00-38.30$ & Gy, Do \pm Anhy & & \\
\hline POS-79 AK5 & $41.63-41.77$ & Gy, Do \pm Anhy & & \\
\hline POS-82 AK2 & $10.00-10.50$ & Gy, Do \pm Anhy, Om & & \\
\hline POS-82 AK3 & $19.70-20.20$ & Gy, Do & & \\
\hline POS-82 AK4 & $31.00-31.50$ & Gy, Anhy, Do $\pm O m$ & & \\
\hline POS-82 AK5 & $34.55-34.75$ & Anhy, Gy, Do \pm Opq & & \\
\hline POS-86 AK1C & $15.39-15.51$ & Gy, Do \pm Anhy, Opq,Q & & \\
\hline POS-86 AK2 & $20.54-20.90$ & Anhy, Do, Gy \pm Om,Opq & \multirow[t]{2}{*}{+} & \\
\hline POS-86 AK3 & $24.15-24.50$ & Anhy, Gy, Do \pm Om, Opq & & \\
\hline POS-86 AK4 & $25.26-25.50$ & Gy, Do $\pm O m, O p q$ & \multirow[t]{4}{*}{+} & \\
\hline POS-86 AK5 & $26.30-26.60$ & Gy, Do \pm Anhy & & \\
\hline POS-86 AK6 & $30.85-31.00$ & Gy, Do $\pm P y$, Anhy, Q & & \\
\hline POS-86 AK7 & $35.92-36.03$ & Anhy, Do \pm Om, Opq & & \\
\hline POS-88 AK2 & $5.20-5.62$ & Gy, Do \pm Py, Anhy, Om & \multirow[t]{6}{*}{+} & \\
\hline POS-88 AK3 & $12.00-12.34$ & Gy, Do \pm Anhy, Opq, Om & & \\
\hline POS-88 AK4 & $26.45-26.63$ & Gy, Do, Anhy $\pm P y, O m, Q$ & & \\
\hline POS-88 AK6 & $46.34-46.68$ & Gy, Anhy $\pm D o$, Om, Q & & \\
\hline POS-88 AK8 & $62.30-62.70$ & Gy, Anhy $\pm D o$, Om & & \\
\hline POS-88 AK9 & $66.45-66.65$ & Gy, Anhy, Do, Om & & \\
\hline POS-91 AK3 & $40.40-40.70$ & Gy, Do \pm Anhy, Om & \multirow[t]{11}{*}{+} & \\
\hline POS-91 AK4 & $56.00-56.40$ & Anhy, Do $\pm G y$, Om & & \\
\hline POS-96 AK4 & $16.48-16.88$ & Gy, Do $\pm O m, O p q, Q$ & & \\
\hline POS-96 AK5 & $23.50-23.75$ & Gy, Do $\pm O m, O p q$ & & \\
\hline POS-112 AK2 & $12.40-12.70$ & Gy, Anhy, Do, Om, Opq & & \\
\hline POS-112 AK3 & $18.00-18.40$ & Gy, Do $\pm O m, O p q, Q$ & & \\
\hline POS-112 AK4 & $24.00-24.20$ & Anhy, Om, Do, Gy & & \\
\hline POS-112 AK5 & $28.00-28.50$ & 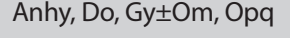 & & \\
\hline POS-124 AK3 & $38.60-39.00$ & Gy, Do $\pm O m, O p q$ & & \\
\hline POS-124 AK4 & $49.20-49.60$ & Anhy, Do \pm Gy, Om, Opq & & \\
\hline POS-124 AK5 & $54.60-55.00$ & Anhy, Gy, Do \pm Om, Opq & & \\
\hline
\end{tabular}




\section{MATERIALS AND METHODS}

Twelve representative drill were selected (from over 100) based on the following criteria: (i) depth of the gypsum, gypsum-anhydrite and anhydrite zones, (ii) associated rocks and macroscopic fabrics, (iii) composition and depth of the overlying deposits and (iv) geographical position of the drill core within the exploitation field. Thin sections of evaporite samples from the gypsum, gypsum-anhydrite transition and anhydrite zones, as well as from the overlying Rauhwacke deposits of the Kosovo polje quarry ( $\mathrm{n}=$ number of samples; $\mathrm{n}=45$; Table 1) were examined under the optical microscope and analyzed by Qwin image analysis software (IM 50 v.1.20). Fluid inclusions were classified according to the criteria summarized by ROEDDER (1984) and SHEPHERD et al. (1985). In addition, carbonate-rich samples were stained according to EVAMY \& SHERMAN, $1962(\mathrm{n}=8$; Table 1) to detect various carbonate minerals.

Clay mineral analysis of the Quaternary cover was performed at the Croatian Geological Survey, Zagreb ( $n=4$; Table 1). Drill-cores were selected according the apparent thickness of clayey cover; three drill-cores having similar cover thickness, $(10-16 \mathrm{~m}$ being the average cover thickness within the deposit), and a single drill-core with a cover thickness of $34 \mathrm{~m}$. A Philips vertical X-ray goniometer (type

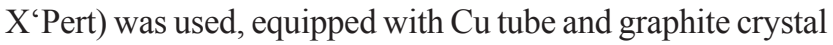
monochromator with the following experimental conditions: $45 \mathrm{kV}, 45 \mathrm{~mA}$, primary beam divergence $1 / 4^{\circ}$, continuous scan (step $0.002^{\circ} 2 \Theta / \mathrm{s}$ ). Obtained spectra were analyzed using X'Pert HighScore plus 2.1 PANalytical B.V. software. Selected Quaternary samples were analyzed according to the BOUDINE \& FERNALLD (1973) method. After carbonate and sulphate dissolution, orientated fraction $<2 \mu \mathrm{m}$ was analyzed 4 times: dry, swelled with ethylene - glycol for 12 hours; heated for $1 / 2$ an hour at $400^{\circ} \mathrm{C}$ and at $550^{\circ} \mathrm{C}$. Clay minerals were determined using a clay mineral identification flow chart. Further analyses such as cation-capacity exchange or glycerin swelling is needed for the positive identification of vermiculite.

\section{RESULTS}

\subsection{Quaternary cover}

\subsubsection{Chemical analysis}

The amount of evaporite within all the investigated samples is uniform and low (3-4 vol \%), however, the amount of carbonate is highly variable, ranging from 9 to 49 vol \%. Eventually, the amount of clayey material ranges from 47 to 88 vol \% (Table 2).

\subsubsection{XRD analysis}

Results of the X-ray diffraction are presented at Fig. 6, and indicate the predominance of an illitic component, the presence of kaolinite and probably vermiculite (MOORE \& REYNOLDS, 1997).

\subsection{Rauhwacke}

Rauhwacke are cavernous carbonate-gypsum breccia usually yellow-brownish in colour. They are composed of up to
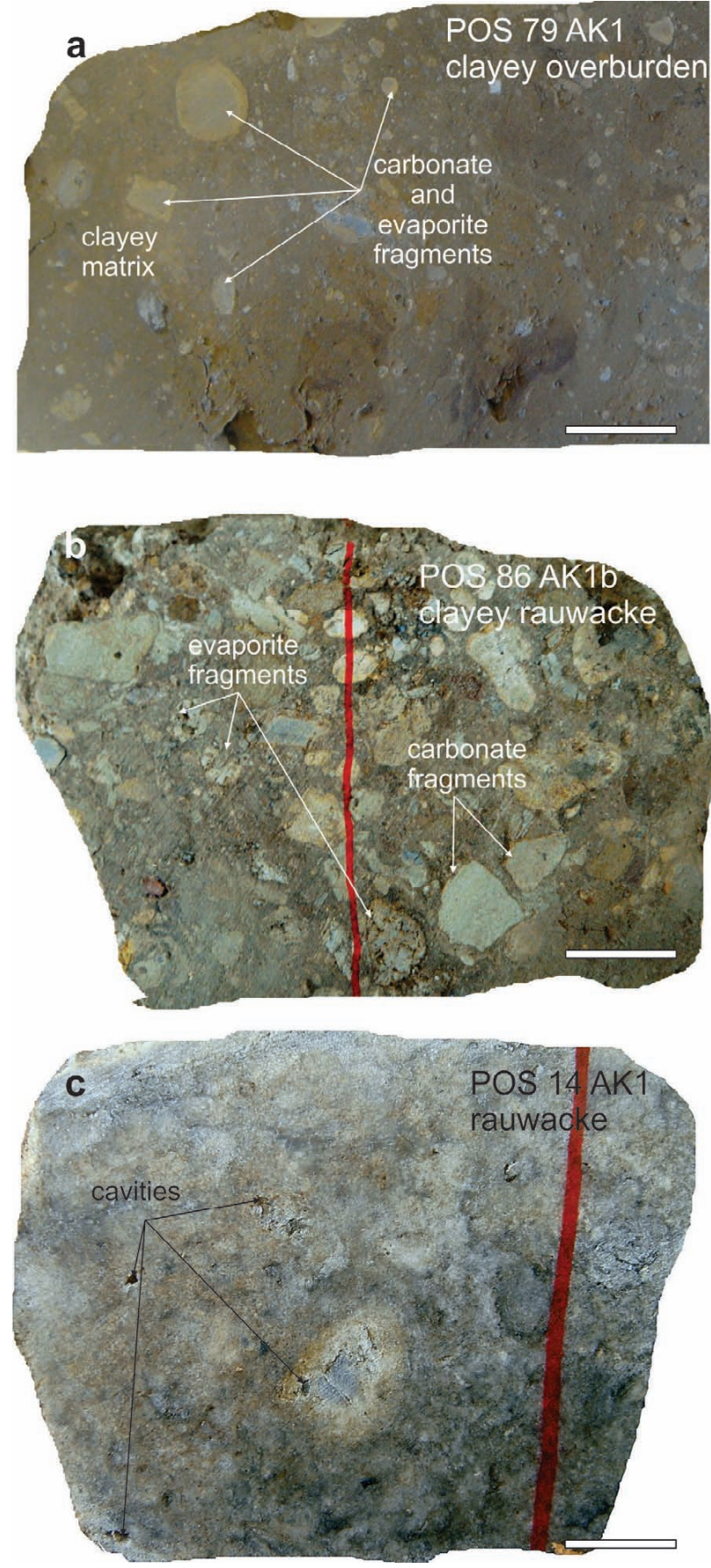

Figure 4: Macrophotographs showing (a) clayey Quaternary cover composed of millimetre to centimetre sized carbonates and evaporites within predominant clayey matrix; (b) cavernous clayey breccia composed of various-sized fragments of limestone, dolostone (sometimes dedolomitized) and partially leached gypsum, cemented with calcite and (c) cavernous breccia - rauhwacke.

Table 2: Chemical analysis of the Quaternary cover samples.

$\begin{array}{lll}\text { Sample no. } & \text { Carbonate amount (\%) } & \text { Evaporite amount (\%) } \\ \text { POS 14 AK1 } & 48.8 & 2.7 \\ \text { POS-79 AK1 } & 49.2 & 2.8 \\ \text { POS-86 AK1 } & 8.9 & 3.9 \\ \text { POS-91 AK1 } & 27.5 & 2.6\end{array}$



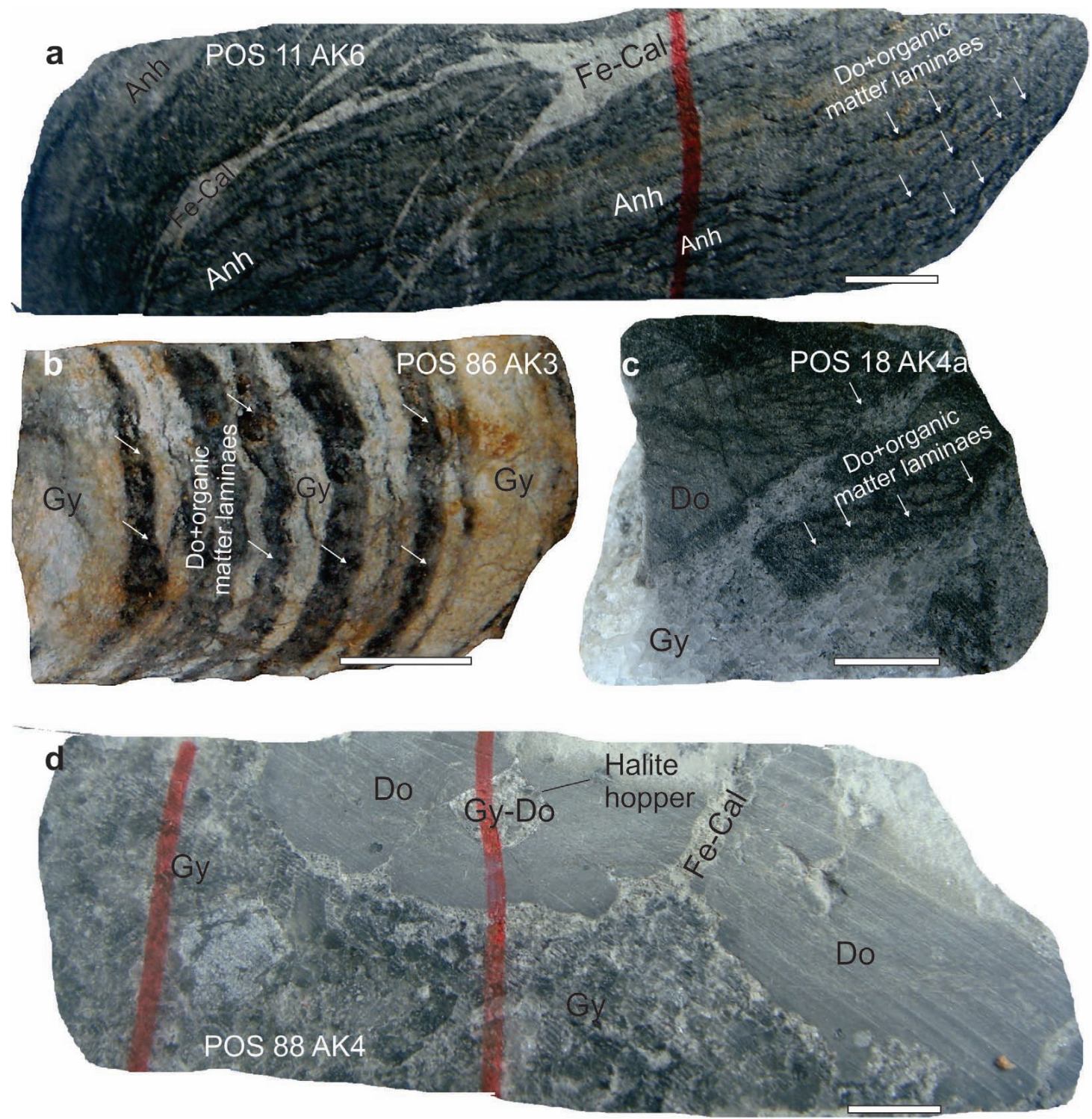

Figure 5: Macrophotographs showing facies-types of the Kosovo polje evaporites: $(a, b)$ laminated evaporite-carbonate facies, composed of millimetre to centimetre gypsum/anhydrite laminas intercalated with dolomite/dolomicrite \pm organic matter \pm siltite; (b, c) evaporite-carbonate breccia facies, composed of millimetre to decametre-sized fragments of laminated evaporites, carbonate and siltite cemented by massive gypsum.

several centimetre-sized carbonate and partially leached gypsum fragments. Vugs, cavities and veinlets are partly cemented by late stage calcite (according to Evamy and Sherman, 1962; Fig. 7). Purple decorated calcite after staining usually occur as anhedral, coarse grained infill $(0.45 \times 0.75 \mathrm{~mm}$ in size; Figs. 7a, b). Dolostone fragments are partly dedolomitized. Dedolomite occurs as very-fine grained anhedral crystals, $0.05 \times 0.2 \mathrm{~mm}$ in size, usually along previous cracks and veinlets of the fragments (Fig. 7a). Evaporite fragments are completely rehydrated and sporadically cavernous.

\subsection{Evaporites}

\subsubsection{Microfabrics}

Microfabric descriptions of the evaporite facies are as follows: (i) Laminated evaporite-carbonate facies consist of millimetre - centimetre thick anhydrite to gypsum laminae (up to $80 \mathrm{vol} \%$ of total rock) with intercalations of thinly $(\mathrm{d}<0.2 \mathrm{~mm}-$ several $\mathrm{mm})$ often disintegrated laminae of fine-grained dolomicrite/ dolomite, organic matter and siltite (up to $20 \mathrm{vol} \%$ of total rock; Figs. 8a, b). Anhydrite regularly appears as nematoblasic and foliated textures, and is often found suppressed by gypsum along the grain boundaries or vinelets (Fig. 8c). Apart from gypsum and anhydrite, these rocks contain dolomicrite laminae with subordinate amounts of organic matter, pyrite, quartz and rock salt. Rock-salt occurs as fine to medium-grained cement, enveloped by organic matter. Dolomicrite laminae are often found disintegrated and composed of dolomite 

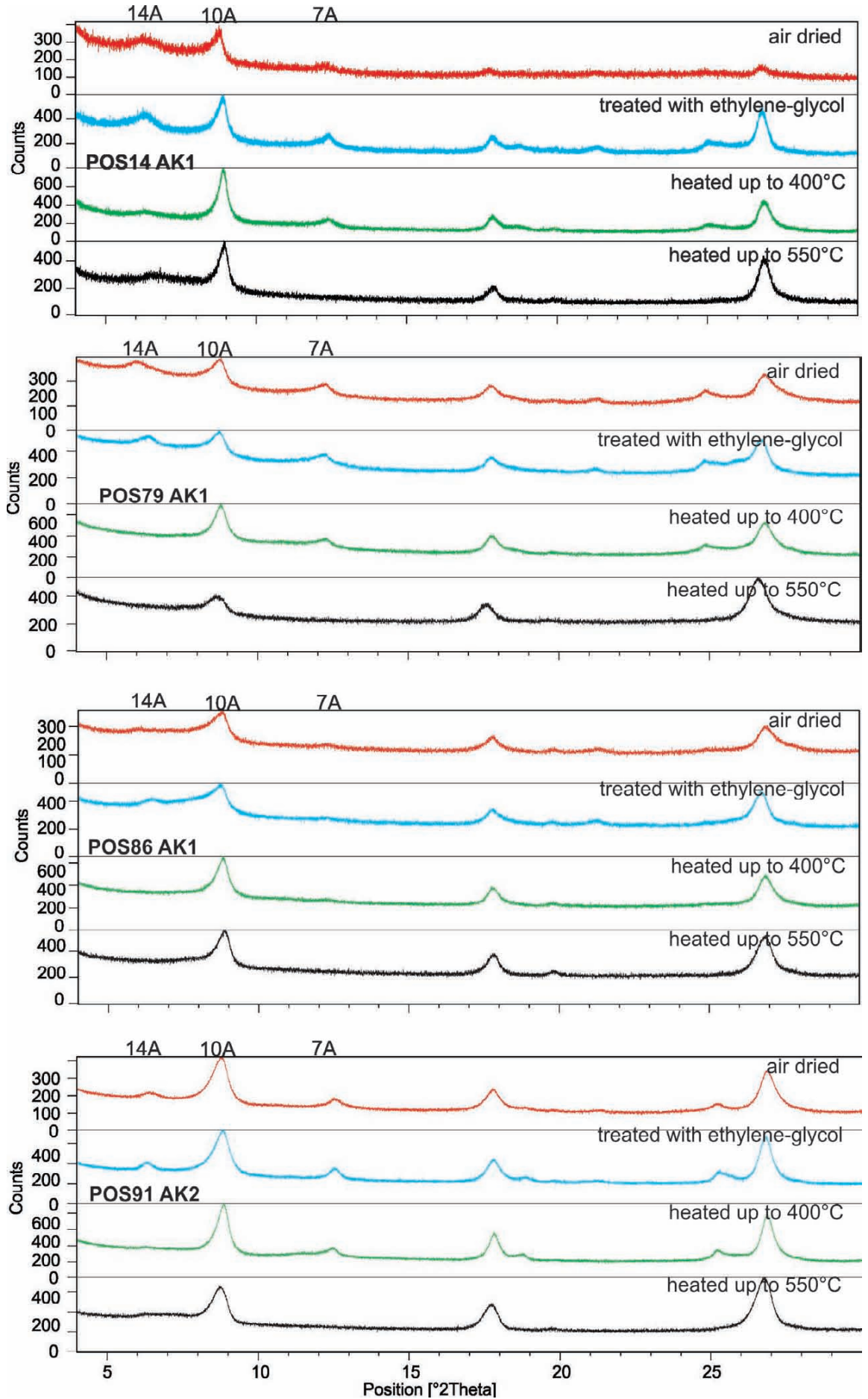

Figure 6: Results of the X-ray diffraction showing $14 \AA \AA, 10 \AA ̊$ and $7 \AA ̊$ peaks interpreted as illite-kaolinite \pm ?vermiculite mixture.

crystals of various sizes associated with granoblastic to porphyroblastic gypsum, while the primary laminated structure remains visible (Fig. 8d). Details of the dolomite classification are given at the end of this section. Laminated facies prevail at the deeper levels of the drill-cores, and the amount of anhydrite increases with depth.

(ii) Evaporite-carbonate breccia is composed of variously sized angular carbonate or laminated evapor- ite fragments $(<5-25 \mathrm{vol} \%$ of the rock) enclosed within massive gypsum. This type of facies prevails at the shallower levels of the evaporite succession. Carbonate fragments are mostly disrupted and composed of tiny dolomite/dolomicrite crystals associated with micron -sized anhydrite and gypsum and crosscut by a network of irregular veinlets filled with fibrous (satin-spar) or granoblastic to porphyroblastic gypsum or anhydrite (Figs. 9a, b, d). In 


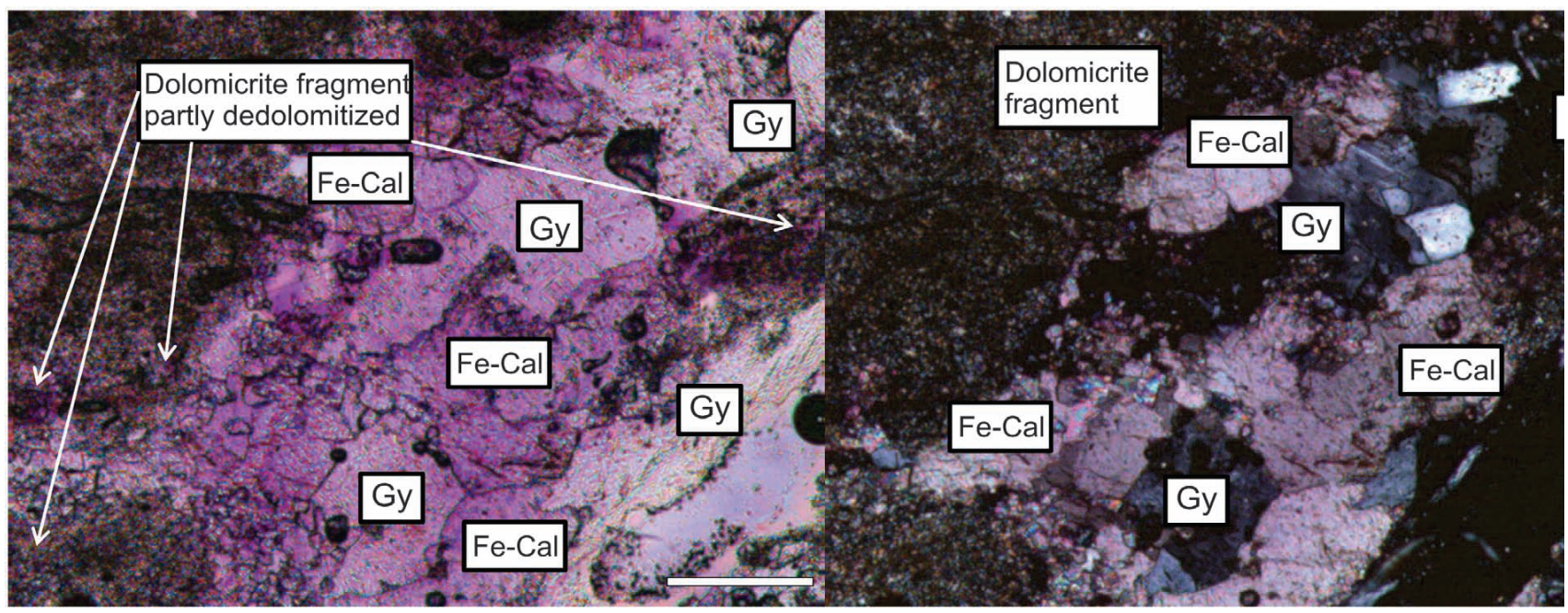

Figure 7: Photomicrographs of the rauhwacke staining showing (a) very-fine grained anhedral dedolomite crystals along previous cracks and veinlets; (b) anhedral, coarse grained infill of the purple decorated calcite.

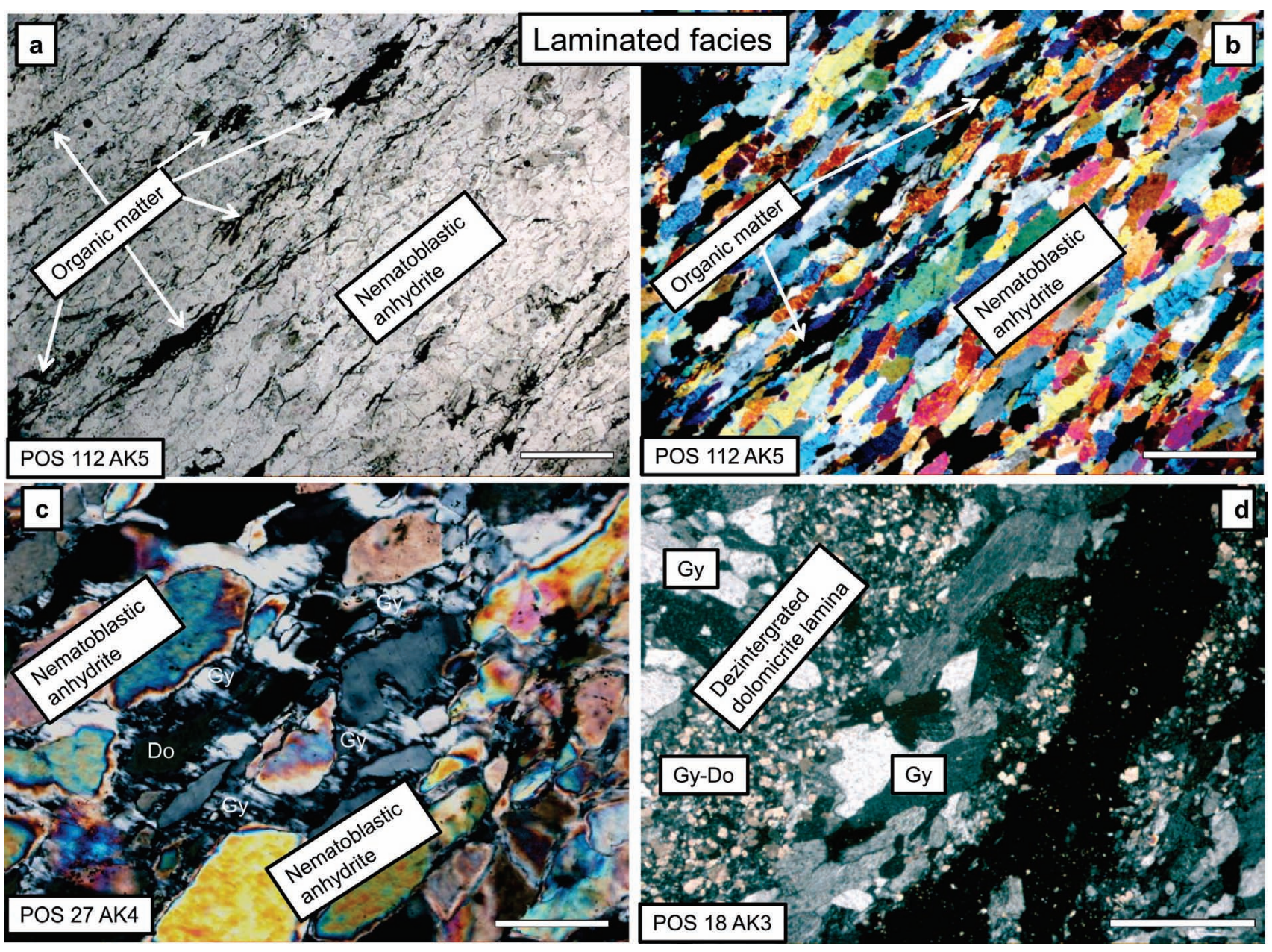

Figure 8: Photomicrographs of the laminated evaporite-carbonate facies consisting of $(a, b)$ millimetres - centimetres thick anhydrite to gypsum laminae with $<0.2 \mathrm{~mm}$ - several $\mathrm{mm}$ thick intercalation of fine-grained, disintegrated dolomicrite/dolomite, organic matter and siltite; (c) nematoblasic and foliated anhydrite suppressed by fibrous gypsum along the grain boundaries or veinlets; (d) gypsum laminae composed of granoblastic to porphyroblastic gypsum, while primary laminated structure remain visible.

addition, carbonate fragments sometimes contain organic matter, clays, (? authigenic) quartz or rock salt textural types as chevron fabrics or individual molds overgrown by the coarse-grained gypsum or a-type to e-type dolomite (Fig. 9c). Fragments of laminated evaporite are carbonate-rich. 


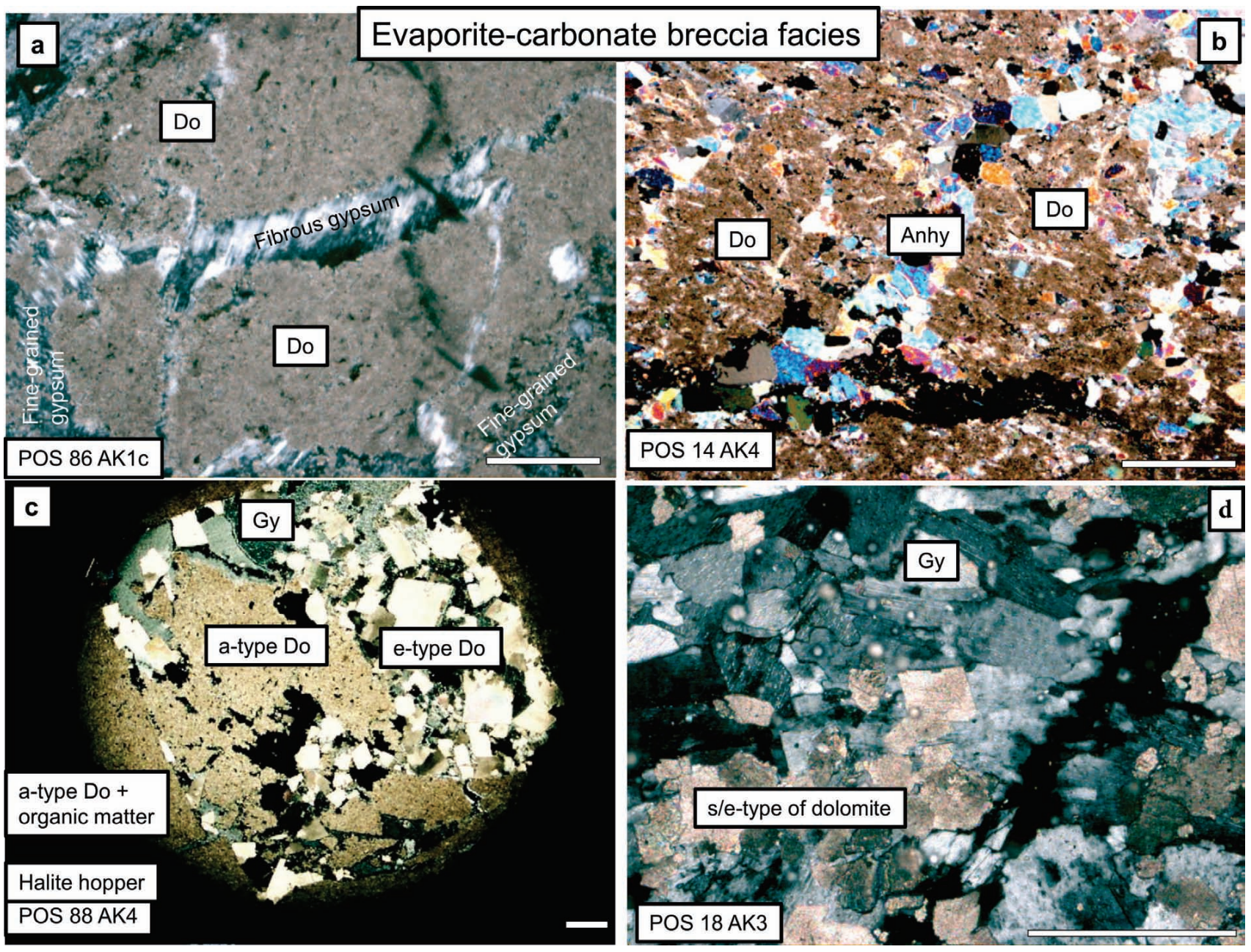

Figure 9: Photomicrographs of the evaporite-carbonate breccia consisting of carbonate or laminated evaporite fragments enclosed within massive gypsum showing: $(a, b)$ mostly disintegrated carbonate fragments composed of micron-sized dolomite/dolomicrite crystals, anhydrite and gypsum crosscut by a network of irregular veinlets filled with fibrous (satin-spar) or granoblastic gypsum to anhydrite; (c) halite mold suppressed by the coarse-grained gypsum and a-type to e-type dolomite; (d) coexistance of granoblastic and porphyroblastic gypsum.

Classification of dolomite/dolomicrite has been done following the criteria of SILBLEY \& GREGG (1987). We have observed three dolomite types (Fig. 10): (i) fine-grained anhedral dolomite or non-planar-a type of dolomite, $<5 \mu \mathrm{m}$ (Fig. 10a); (ii) fine- to medium-grained subhedral dolomite or planar-s

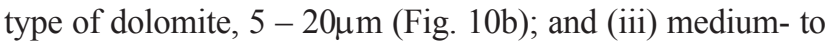
coarse-grained euhedral dolomite or planar-e type of dolomite (Fig. 10c). Non-planar-a type and subhedral-s type of dolomite appears regularly throughout entire evaporite succession, whereas the planar-e type of dolomite prevails at the shallower levels of the evaporite succession, mostly related to the evaporite-carbonate breccia facies. Carbonate staining shows evidence of minor dedolomitization at the uppermost levels of the deposit (EVAMY \& SHERMAN, 1962). Dedolomites are usually of radial appearance enveloped by randomly orientated fine-grained gypsum (Fig. 10d).

\subsubsection{Fluid inclusion petrography}

Coarse-grained granoblastic to porphyroblastic gypsum contains primary and pseudosecondary monophase, liquid fluid inclusions (according to the criteria of ROEDDER, 1980 and
SHEPHERD et al., 1985), located within three-dimensional clusters and subparallel trails within a single crystal, respectively (Figs. 11a, b). Anhydrite and dolomite do not host visible fluid inclusions.

\section{DISCUSSION}

Figure 12 presents a model for the evolution of the Kosovo polje evaporites, based on the aforementioned data. Laminated facies composed of millimetre to centimetre thick intercalations of evaporite and dolostone (sometimes bearing organic matter, pyrite, quartz, halite) were interpreted by TIŠLJAR (1992) as having originated from Late Permian sabkha-type or lagoon-type of the environment. Due to burial, the thickness of the overlying deposits increased (i. e. increasing lithostatic pressure and temperature), triggering the onset of the following diagenetic processes: (i) precipitation of secondary diagenetic halite from supersaturated solutions within carbonate, organic rich laminas, (ii) dolomitization and (iii) dehydratation of gypsum. The latter two processes led to strong volume decreases of $12 \%$ and $39 \%$, respectively, followed by additional micro-cracking and re- 
crystallization, especially within the dolomicrite member. Severe tectonic movements during the exhumation phase led to the formation of the evaporite-carbonate breccia at the upper parts of the evaporite complex. Exhumation processes were followed by widespread rehydratation of gypsum and partial dedolomitization, mainly in the uppermost levels of the deposit. Description and clarification of these diagenetic processes is given below.

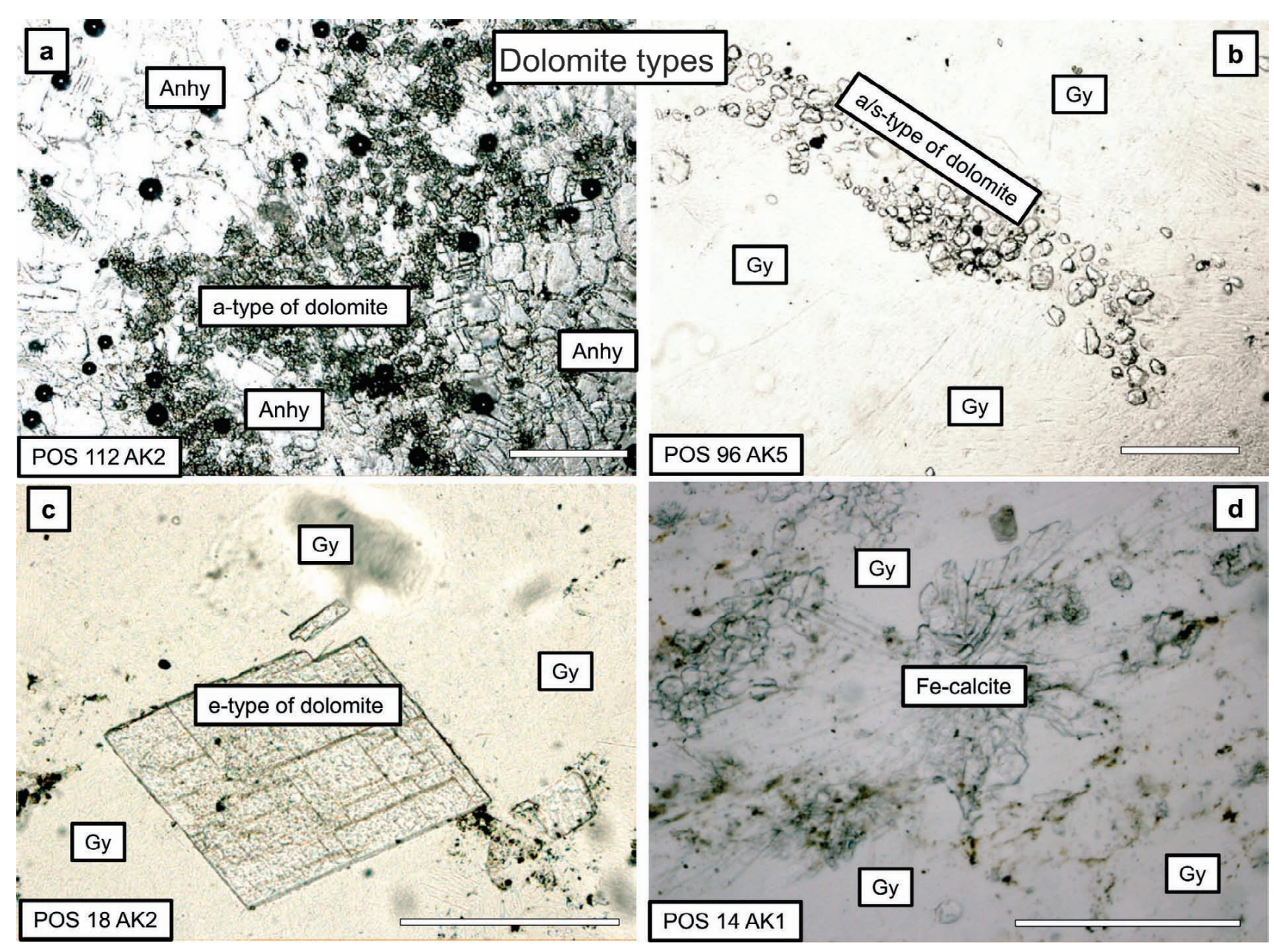

Figure 10: Photomicrographs of the dolomite/dolomicrite. Classification follows criteria according to SIBLEY and GREGG (1987): (a) fine-grained anhedral dolomite or non-planar-a type of dolomite; (b) fine- to medium-grained subhedral dolomite or planar-s type of dolomite, and (c) medium- to coarsegrained euhedral dolomite or planar-e type of dolomite and (d) Bunch-like radial dedolomite enveloped by fine-grained gypsum from the uppermost part of the evaporite sequence.
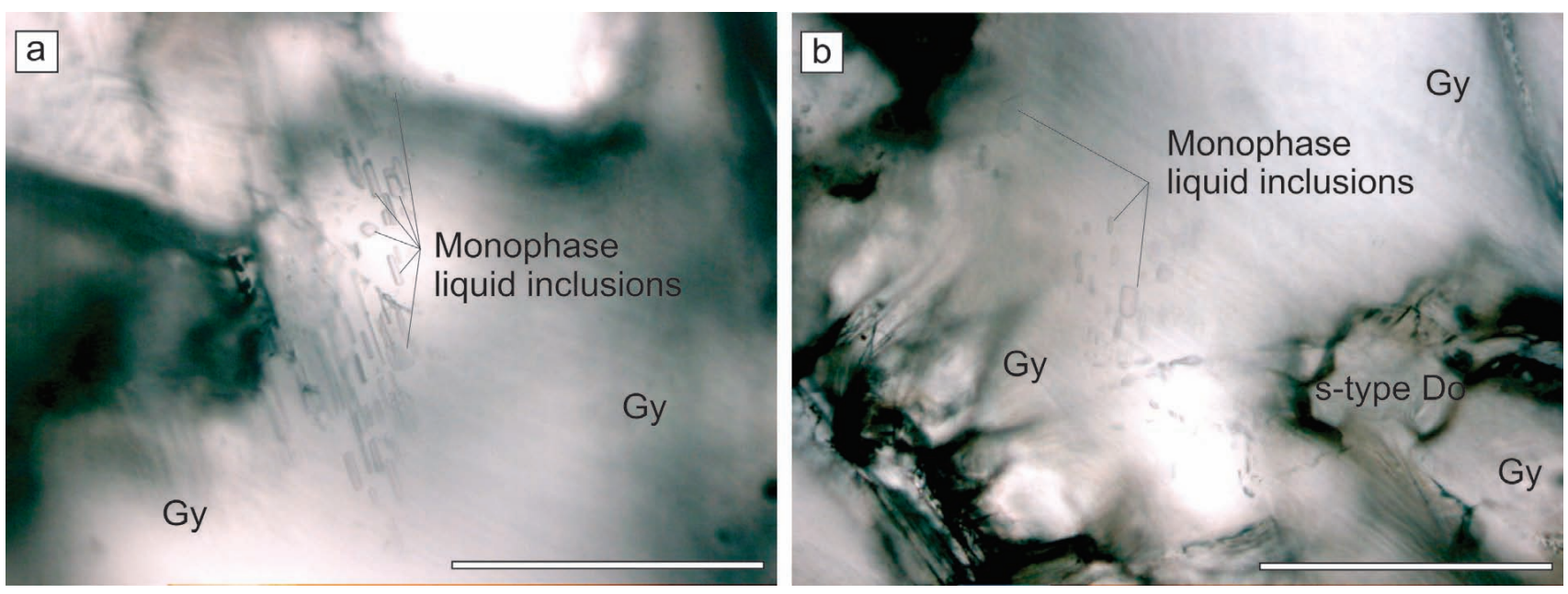

Figure 11: Fluid inclusion petrography of the coarse-grained granoblastic to porphyroblastic gypsum showing $(a, b)$ three-dimensional clusters and subparallel trails primary and pseudosecondary monophase, liquid fluid inclusions (according to criteria of ROEDDER, 1980 and SHEPHERD et al., 1985). 


\subsection{Early diagenesis and burial}

\subsubsection{Diagenetic halite}

During the evaporation of seawater in the restricted pools or sabkhas, a normal succession would precipitate calcium carbonate, gypsum and halite at a brine concentration of about 1.8, 3.8 and 10.6 times greater than seawater, respectively (McCAFFREY et al., 1987). Therefore, primary halite laminae or deposits would have to occur superimposed on the gypsum - anhydrite laminae or layers. However, within the Kosovo polje deposit, halite is associated with organic-rich dolomicrite/dolomite laminae or fragments and is sometimes overgrown by gypsum and a-type to e-type dolomite. Based on their textural characteristics, both types are interpreted as secondary (WARREN, 2006), and originated from supersaturated subsurface or surface (lagoonal) brines that differ in chemistry and salinity from the primary brines that precipitated carbonate laminae.

\subsubsection{Dolomitization}

Diagenetic processes in the shallow burial realm are controlled strongly by early dolomitization which is either attributed to the seepage-reflux model (e.g. MATTES \& CONWAY MORRIS, 1990) or triggered by reducing conditions induced from removal of $\mathrm{SO}_{4}{ }^{2-}$ by sulphate reducing bacteria (e.g. GINGRAS et al., 2004). According to the seepage-reflux model, dolomitization occures prior to replacement of connate water within permeable carbonates at the lagoon floor with hypersaline, heavy lagoon brine (ADAMS \& RHODES, 1960). On the other hand, bacteria induced reducing conditions accompanied by metal enrichment additionally faciliate dolomite precipitation (MIRSAL \& ZANKL, 1985). These types of processes likely occured within organic-rich, pyriteassociated carbonate laminae of the Kosovo polje. The existance of idiomorphic planar-e type dolomite crystals indicates precipitation at temperatures below $50-60^{\circ} \mathrm{C}$, which again, points to early formation in a shallow burial realm.

The predominant non-planar-a type of dolomite/dolomicrite are likely to be related to burial dolomitization at temperatures exceeding $\sim 50^{\circ} \mathrm{C}$ (SIBLEY \& GREGG, 1987; WARREN, 2000). When evaporite successions reach depths of 2-3 $\mathrm{km}$, temperature increases above $\sim 60^{\circ} \mathrm{C}$ which enables dolomitization by solutions with lower $\mathrm{Mg} / \mathrm{Ca}$ ratios. Therefore residual evaporite brines or seawater can become dolomitizing solutions (WARREN, 1999). The amount of non-planar-a type of dolomite generally increases with depth, whereas volumetrically, minor planar-e type of dolomite generally occurs in the uppermost gypsum or gypsum-anhydrite zone.

\subsubsection{Gypsum dehydration}

Gypsum dehydration begins under similar conditions to dolomitization. When temperatures within the evaporite exceed $60^{\circ} \mathrm{C}$ (HARDIE, 1967; JOWETT et al., 1993; WARREN, 2006) or the thickness of the overlying deposits exceeds 1000 m (SHEARMAN 1995) primary sabhka-type of gypsum will start to dehydrate, leading to the formation of anhydrite. In addition to temperature (and lithostatic pressure), the depth of gypsum to anhydrite transition depends on pore water salinity and pressure and heat flow. Under high

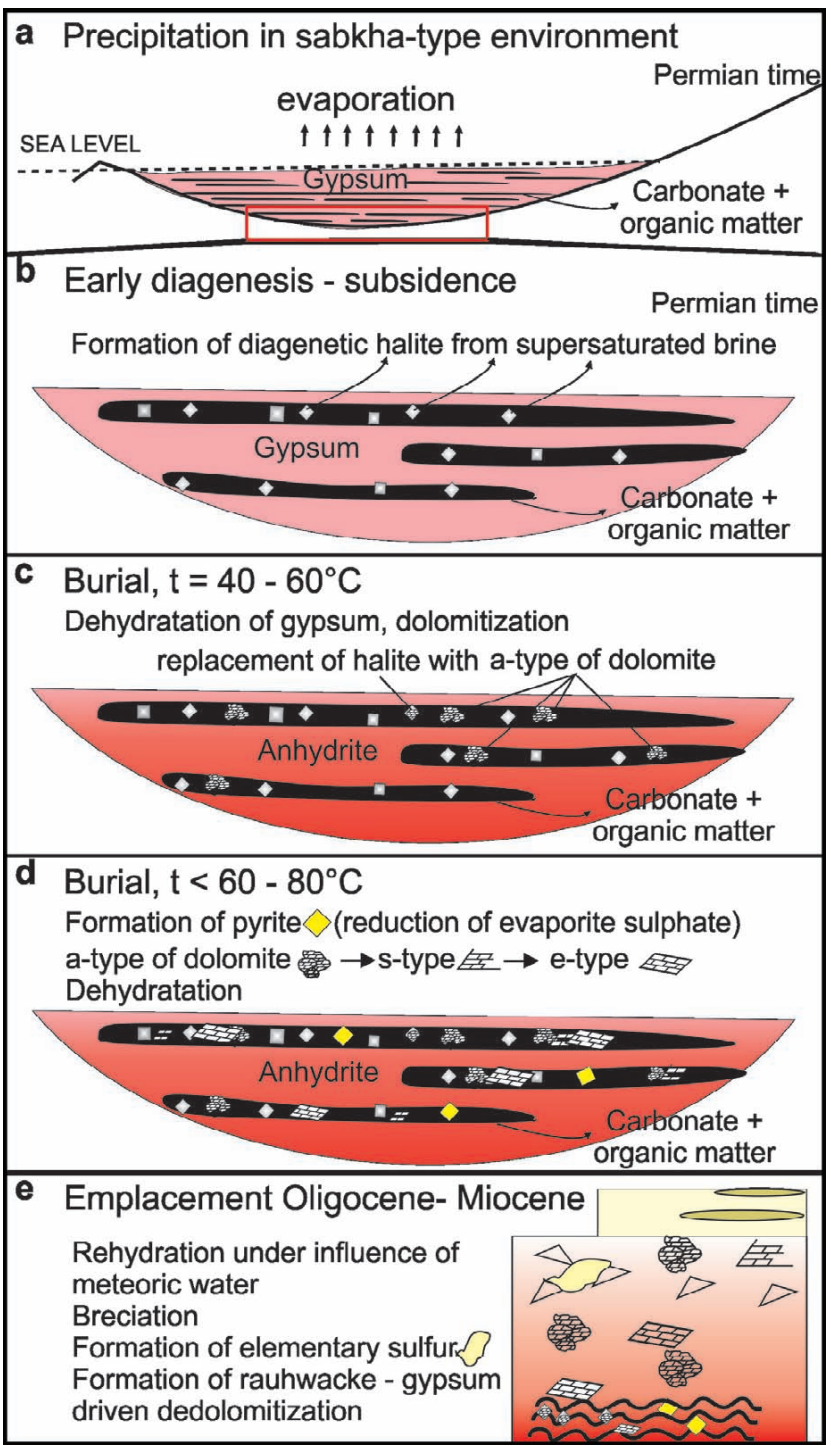

Figure 12: Model for the evolution of the Kosovo polje evaporites. See text for discussion.

salinity pore water this transition is plausible at rather low temperatures $\left(\mathrm{T}>40^{\circ} \mathrm{C}\right.$; YAMAMOTO \& KENNEDY, 1969), whereas overlying conductor rocks imply transition at relatively shallow depths (>400 m; JOWETT et al., 1993). Water liberated via this process is a Ca-saturated and halite under saturated brine, escaping into the subjacent evaporite or clastic sediments. This type of brine is most likely responsible for dissolution of halite and formation of molds within the Kosovo polje carbonates. Dissolution of halite could also occur during regional uplift and flushing of evaporites by meteoric water.

\subsubsection{Pyrite and sulfur}

Although minor, the occurrence of pyrite within organic rich intercalations of the dolomicrite member and elementary sulfur as cement of the evaporite-carbonate breccia brings us some insight into the geological environment. Within the evaporite deposits, metal sulfides and sulfur are formed as the result of the biochemical or thermochemical reduction 
of evaporite sulphate to sulfide, followed by oxidation to native sulfur (e.g. MACHEL, 2001; ORTI et al., 2010; ZIEGENBALG et al., 2010 and references therein). Biochemical reactions include low-temperature (up to $60-80^{\circ} \mathrm{C}$ ) bacterial reduction of evaporite sulphate to hydrogen sulfide, whereas thermochemical reactions envisage hydrocarbonsdriven thermal reduction of evaporite sulphate to hydrogen sulfide at temperatures of approximately $100-140^{\circ} \mathrm{C}$. In both cases, a part of the liberated hydrogen sulfide will rapidly react with available metals, especially Fe which is commonly associated with burial sedimentary environments. $\mathrm{SO}_{4}{ }^{2-}$ removal - metal enrichment processes faciliate dolomite precipitation (MIRSAL \& ZANKL, 1985). After the system runs out of iron, hydrogen sulfide will oxidize to native sulfur under the influence of meteoric or other oxygenated surface or subsurface waters. Within the Kosovo polje, pyrite is observed exclusively associated with the organic rich intercalation of the dolomicrite member, implying an active role of organic matter within the reduction process. However, elementary sulfur occurs as cement of the evaporite-carbonate breccia (together with prevailing gypsum) and related to tectonic emplacement of the evaporites, thus indicating late stage hydrogen-sulfide oxidation. Maximum burial temperatures of the Kosovo polje evaporites are not clear, however, burial history revealed from deep drill-cores $(>4500 \mathrm{~m})$ of the nearby Ravni Kotari antiform imply that the burial temperature of the ,alterations of the early-diagenetic dolomite, anhydrite, limestone and argilitic-limestone" did exceed the oil-window $\left(\sim 120^{\circ} \mathrm{C}\right)$, at least for the Ravni Kotari structures (sensu GRANDIĆ et al., 1997). The absence of saddle (baroque) dolomite from the Kosovo polje succession indicates that higher burial conditions (exceeding 60 to $150^{\circ} \mathrm{C}$ ) were not achieved; therefore, low temperature biochemical reduction of evaporite sulphate is more probable.

\subsection{Emplacement}

\subsubsection{Rehydration}

Rehydration of anhydrite to gypsum occurs during exhumation conditions under the influence of meteoric water. This process led to the formation of granoblastic or porphyroblastic gypsum, volume increase and enterolithic folding, visible at both the micro and macro- scales. Rehydrated gypsum encloses relics of anhydrite. The fluid inclusion assemblage, discovered within granoblastic to nematoblastic gypsum of the Kosovo polje, retains halite undersaturated monophase, liquid-only inclusions, most likely of meteoric-water origin. The width of the rehydration zone (gypsum zone and anhydrite to gypsum transition zone), shows a negative correlation with the thickness of the overlying Quaternary cover, as well as with the amount of clayey material within it. Drillcores with thick cover $(20-30 \mathrm{~m})$ have a rehydration zone only several metres thick, whereas with decreasing thickness of the cover deposits, the rehydration zone exceeds $50 \mathrm{~m}$ in thickness. Quaternary cover is composed predominantly of carbonates and illite-kaolinite clayey material with the addition of swelling clay and evaporites ( $<4$ vol \%). The carbonate to clay ratio of the Quaternary cover also varies strongly, and seems to be related to the thickness of the underlying rehydrated evaporite. Within the drill-cores where the cover thickness is similar, clay-rich cover material $(>80$ vol \% of clays) are underlain by a thin gypsum $(<10 \mathrm{~m})$ and anhydrite to gypsum transition zone $(<15 \mathrm{~m})$, whereas drillcores with a carbonate-rich cover ( $\sim 50$ vol \% of clays) display increasing thicknesses of rehydrated evaporates $(>30 \mathrm{~m})$.

Formation of fibrous or satinspar gypsum within veinlets, cavities or fractures crosscutting the coarse-grained gypsum and anhydrite of the Kosovo polje is most likely to be related to late stage fluid flow.

\subsubsection{Karstification and dedolomitization}

Formation of rauhwacke subsequent to evaporite rehydration follows when an increased amount of gypsum is leached under the influence of meteoric water from the uppermost evaporite-carbonate breccia. Gypsum dissolution processes control and facilitate dissolution of the associated dolomite, followed by calcite precipitation throughout a process described in the literature as gypsum-driven dedolomitization (BISCHOFF et al., 1994 and references therein). The precipitation of calcite removes dolomite-supply carbonate ion and gypsum-supply calcium ion from the solution, thereby causing further dolomite and gypsum dissolution. Finally, this type of process, together with tectonic movements resulted in the formation of rauhwacke deposits (several metres thick), on top of the evaporite succession of the Kosovo polje.

\subsection{Correlation with the Burrano formation, Northern Apennines}

The Permian to Triassic Dinaric evaporite mélange shows notable similarities with the Upper Triassic Burano Evaporite formation, located in the Northern Apennines (Secchia River Valley; LUIGI, 2001 and references therein) as follows:

(i) The Burrano and Dinaric evaporite formations are both strongly tectonized sequences with limited vertical and lateral continuity, composed of intercalations of gypsum \pm anhydrite and boudinage dolostones with minor halite. Evaporite-carbonate intercalations of the Burano formation are generally thicker (metre to decametre), and interpreted as subaqueous (LUIGI, 2001) whereas within the Dinarides, intercalations appear to be much thinner (millimetre to centimetre), and are considered to be of sabhka origin (TIŠLJAR, 1991). In addition, Dinaridic dolomicrite laminae contain organic matter, pyrite, quartz and rock salt.

(ii) Both formations are thrusted onto younger Mesozoic formations and interpreted as a main decollement horizon during the Oligocene-Miocene shortening at the Adriatic-Dinaric domain.

(iii) Dinaride evaporites are associated with magmatic and sedimentary rocks, while the Burano evaporites are associated with greenshist types of metasediments related to thrusting, and suffered secondary Mg-metasomatic replacement with temperatures around $300^{\circ} \mathrm{C}$.

(iv) Due to surface exposure and leaching, both evaporite formations are covered with cavernous dedolomitized breccia-rauhwacke. 


\section{CONCLUSION}

Evaporite rocks of the Kosovo polje deposits are associated with carbonates, clastic and minor albitized subvolcanic neutral to basic rocks and represent a part of the Dinaric evaporite mélange. They are capped by clayey Quaternary cover and cavernous carbonate breccia - rauhwacke, several metres thick. Evaporite rocks show two distinct facies: laminated evaporite-carbonate facies, composed of evaporite and dolomicrite ( \pm organic matter, pyrite, halite) intercalations, related to primary sabhka deposition, and evaporite-carbonate breccia facies, composed of fragments of laminated evaporites, carbonate and siltite, cemented by massive gypsum \pm sulfur, occurring at shallower levels and related to the emplacement. Quaternary cover is composed of $47-88 \%$ clayey material, consisting of illite, kaolinite and most likely vermiculite, $9-49 \%$ carbonate and $3-4 \%$ evaporite. The width of the evaporite rehydration zone correlates negatively with the thickness of the overlying Quaternary cover and with the amount of clayey material within it. Rauhwacke are composed of partly dedolomitized carbonate and leached gypsum fragments, cemented with late stage calcite.

Diagenetic processes postdating primary sabhka deposition of the evaporite formation are related to early diagenesis, burial and the emplacement phase as follows:

- formation of diagenetic halite from oversaturated subsurface or surface (lagoon) brine biochemical reduction of evaporite sulphate to sulfide followed by formation of pyrite within organic-rich carbonate laminas.

- early dolomitization in a shallow burial realm within organic-rich, pyrite-associated carbonate laminas controlled by bacteria induced reducing conditions and formation of idiomorphic planar-e type of dolomite crystals at temperatures below $50-60^{\circ} \mathrm{C}$ dissolution of diagenetic halite and formation of molds with planar-e type of dolomite

- onset of gypsum dehydration at temperatures of $40-$ $60^{\circ} \mathrm{C}$

- onset of burial dolomitization of carbonate mud at temperature exceeding $\sim 50^{\circ} \mathrm{C}$ and precipitation of fine grained non-planar-a type of dolomite

- replacement of planar-e type of dolomite within molds with a non-planar-a type of dolomite

- rehydration of anhydrite to gypsum under the influence of low-temperature undersaturated fluid (meteoric water)

- late stage oxidation of hydrogen-sulfide to elementary sulfur, occurring as cement in the evaporite-carbonate breccia

- formation of rauhwacke throughout a gypsum-driven dedolomitization process.

\section{ACKNOWLEDGEMENT}

The Knauf company supported the visit of A. KULUŠIĆ to the drill-core storage in Iphofen, Germany. Authors are grateful to M. HOLZAPFEL, N. STELZER, S. RAK, S. LOVRINOVIĆ and M. PUTAR for logistical help, discussion and their knowledgeable input. The help of Nikolina ILIJANIĆ in per- forming XRD analysis at the Department of mineral deposits, Croatian Geological Survey is highly appreciated. The authors highly appreciated comments and suggestions of Stefano LUGLI and an anonymus reviewer that clarified the final version of the manuscript. Editorial handling by Mirko BELAK.

\section{REFERENCES}

ADAMS, J.F. \& RHODES, M.L. (1960): Dolomitization by seepage refluxion.- Am. Assoc. Petrol. Geol. Bull., 44, 1912-1920.

BABIĆ, K. (1990): Tektonska kretanja i solne strukture u području VisBiševo-Sušac [Tectonic movements and salt structures in the area of Vis-Biševo-Sušac - in Croatian with an English abstract].- Unpublished MS Thesis, Faculty of Science, University of Zagreb, $50 \mathrm{p}$.

BARIĆ, LJ. (1969): Eruptivgesteine (albitisierte Diabase) in der Umgebung von Sinj, Dalmatien.- Geol. vjesnik 22, 349-410.

BISCHOFF, J.L., JULIA, R., SHANKS, W.C. \& ROSENBAUER, R.J. (1994): Karstification without carbonic acid: Bedrock dissolution by gypsum-driven dedolomitization.- Geology, 995-998.

BELAK, M., KOCH, G., GRGASOVIĆ, T., VLAHOVIĆ, I., VELIĆ, I., SOKAČ, B. \& BENČEK, Đ. (2005): Novi prinosi stratigrafij i evaporitno-karbonatno-klasatično-vulkanogenog kompleksa Komiškog zaljeva (otok Vis, Hrvatska) [New Contribution to the Stratigraphy of Evaporitic-Carbonate-Clastic-Volcanogenic Complex of Komiža Bay (Island of Vis, Croatia) - in Croatian].- In: VELIĆ, I., VLAHOVIĆ, I. \& BIONDIĆ, R. (eds.): 3. Hrvatski geološki kongres, (3rd Croatian Geological Congress), Opatija 29.09.-01.10. 2005., Knjiga sažetaka (Abstract Book), Hrvatski geološki institut - Croatian Geological Survey, Zagreb, 13-14.

BELAK, M. \& GEORG, K. (2009): Evaporitno-karbonatno-klastičnovulkanogeni kompleks (gornji ladinik, karnik $-\mathrm{T}_{2}{ }^{2}, \mathrm{~T}_{3}{ }^{1}$ ) [Evaporitic-Carbonate-Clastic-Volcanogenic Complex (Upper Ladinian, Carnian $\left.-T_{2}{ }^{2}, T_{3}{ }^{l}\right)$ - in Croatian].- In: VELIĆ, I. \& VLAHOVIĆ, I (eds): Tumač Geološke karte Republike Hrvatske 1:300.000 Zagreb, Hrvatski geološki institut, p. 38.

BODINE, M.W., J.R. \& FERNALLD, T. H. (1973): EDTA dissolution of gypsum, anhydrite, and Ca-Mg carbonates.- J. Sed. Petrol., 43, $1152-1156$.

BOROJEVIĆ-ŠOŠTARIĆ, S. \& NEUBAUER, F. (2012): Principle rock types for radioactive waste repositories.- RGN Zbornik, 24, 11-18.

DAVIS, D.M. \& ENGELDER, T. (1985): The role of salt in fold-andthrust belts. Tectonophysics, 119, 67-88.

DE MIN, A., JOURDAN, F., MARZOLI, A., RENNE, P.R. \& JURAČIĆ M. (2009): The tholeiitic Magmatism of Jabuka, Vis and Brusnik Islands: a Carnian magmatism in the Adria Plate-- Rendiconti online Soc. Geol. It., 9, 85-87.

EVAMY, B.D. \& SHERMAN, D.J. (1962): The application of chemical staining techniques to the study of diagenesis in limestones.- Proc. Geol. Soc., London, 1599, 102.

GABRIĆ, A., ŠINKOVEC, B., SAKAČ, K. \& KULJAK, G. (2002): Ležišta gipsa u Republici Hrvatskoj [Gypsum deposits of the Republic of Croatia - in Croatian with an English abstract].- RGN zbornik, Zagreb 14, 21-36.

GELETTI, R., DEL BEN, A., BUSETTI, M., RAMELLA, R. \& VOLPI, V. (2008): Gas seeps linked to salt structures in the Central Adriatic Sea.- Basin Res., 20/4, 473-487.

GRANDIĆ, S., BOROMISA-BALAŠ, E. \& ŠUŠTERČIĆ, M. (1997): Exploration concept and characteristic of the Dinarides stratigraphic and structural model in the Croatian offshore area, Part 1.- Nafta, 4, Zagreb, 117-128.

GRANDIĆ, S., KRATKOVIĆ, I., KOLBAH, S. \& SAMARŽIJA, J. (2004): Hydrocarbon potential of stratigraphic and structural traps of the Ravni Kotari area - Croatia.- Nafta, 55/7-8, 311-327.

GRIMANI, I., ŠIKIĆ, K. \& ŠIMUNIĆ, A. (1962 - 1966): Osnovna geološka karta SFRJ 1:100000, list Knin L33-141 [Basic Geolog- 
ical Map of SFRY 1:100000, Knin sheet - in Croatian].- Geološki zavod, Zagreb, Savezni geološki zavod, Beograd.

HARDIE, L.A. (1967): The gypsum-anhydrite equilibrium at one atmosphere pressure.-Am. Min., 52, 171-200.

HERAK, M. (1973): Some tectonic problems of the evaporitic area in the Dinarides of Croatia.- Geol. vjesnik, 26, 29-40.

HERAK, M. (1986): A new concept of geotectonics of Dinarides.-Acta Geologica, Jugosl. akad. znan. i umjet., 16, Zagreb, 1-42.

IVANOVIĆ, A., SIKIRICA, V., MARKOVIĆ, S. \& SAKAČ, K. (1967 - 1972): Osnovna geološka karta SFRJ 1:100000, list Drniš K33-9 [Basic Geological Map of SFRY 1:100000, Drniš sheet - in Croatian].- Geološki zavod, Zagreb, Savezni geološki zavod, Beograd.

JOWETT, C.E., CATHLES, L.M. \& DAVIS, B.W. (1993): Predicting depths of gypsum dehydration in evaporitic sedimentary basins.AAPG Bulletin, 77/3, 402-413.

KORBAR, T. (2009): Orogenic evolution of the External Dinarides in the NE Adriatic region: a model.- Earth Sci. Rev., 96, 296-312.

KORBAR, T., MONTANARI, A., KOCH, G., MARIANI, S., DEPAOLO, D., TURCHYN, A.V., MIKNIĆ, M. \& TARI, V. (2009): Geologic reconnaissance of the island of Velika Palagruža (central Adriatic, Croatia).-- Geol. Croat., 62/2, 75-94.

LUGLI, S. (2001) Timing of post-depositional events in the Burano Formation of the Secchia valley (Upper Triassic, Northern Apennines), clues from gypsum \pm anhydrite transitions and carbonate metasomatism.--Sedim. Geol., 140, 107-122.

MACHEL, H.G. (2001): Bacterial and thermochemical sulfate reduction in diagenetic settings — old and new insights.- Sedim. Geol., 140, $143-175$.

MATTAVELLI, L., NOVELLI, L. \& ANELLI, L. (1991): Occurence of hydrocarbons in the Adriatic basin.-Spec. Publ. EAPG, 1, 369-380.

MATTES, B.W. \& CONWAY MORRIS, S. (1990): Carbonate/evaporite deposition in the Late Precambrian-Early Cambrian Ara formation of Southern Oman.- In: ROBERTSON, A.H.F., SEARLE, M.P. \& RIES, A.C. (eds.): The Geology and Tectonics of the Oman Region.- Geol. Soc. London Spec. Publ., 49, 617-636.

McCAFFREY, M.A., LAZAR, B. \& HOLLAND, H.D. (1987.): The evaporation path of seawater and the coprecipitation of $\mathrm{Br}$ (super -) and K (super +) with halite.- J. Sed. Res., 57, 928-937.

MIRSAL, I.A. \& ZANKL, H. (1985): Some phenomenological aspects of carbonate geochemistry: the control effect of transition metals.Geol. Rundsch., 74, 367-377.

MOORE, D. \& REYNOLDS, R.C. (1997): X-ray diffraction and the identification and analysis of clay minerals, 2nd ed.- Oxford University press, New York.

ORTÍ, F., ROSELL, L. \& ANADÓN, P. (2010): Diagenetic gypsum related to sulfur deposits in evaporites (Libros Gypsum, Miocene, NE Spain).- Sedim. Geol., 228, 304-318.

PALINKAŠ, L.A., BOROJEVIĆ ŠOŠTARIĆ, S., STRMIĆ PALINKAŠ, S., CRNJAKOVIĆ, M., NEUBAUER, F., MOLNAR, F. \& BERMANEC, V. (2010): Volcanoes in the Adriatic Sea: Permo-Triassic magmatism on the Adriatic-Dinaridic carbonate platform.- Acta Mineral. Petrogr., 8, 1-15.

PAMIĆ, J. (1984): Triassic magmatism of the Dinarides in Yugoslavia.Tectonophysics, 109, 273-307.

PAMIĆ, J. \& BALEN, D. (2005): Interaction between Permo-Triassic rifting, magmatism and initiation of the Adriatic-Dinaridic carbonate platform (ADCP).- Acta Geol. Hung., 48/2, 181-204.

PAMIĆ, J., GUŠIĆ, I. \& JELASKA, V. (1998): Geodynamic evolution of the Central Dinarides.- Tectonophysics, 297, 251-268.

PAPEŠ, J., MARINKOVIČ, R., RAIĆ, V., MAGAŠ, N. \& SIKIRICA, V. (1968-1980): Osnovna geološka karta SFRJ 1:100000, list Sinj
K33-10 [Basic Geological Map of SFRY 1:100000, Sinj sheet - in Croatian].- Geološki zavod, Zagreb, Savezni geološki zavod, Beograd.

ROEDDER, E. (1984): Fluid inclusions.- Mineral. Soc. Amer., Rev. Mineral., Washington, 12, $644 \mathrm{p}$.

ŠĆAVNIČAR, B. (1973): Halite molds within clastite from Vrlika and Knin area.- Geol. vjesnik, 26, 155-157.

SCHMID, S.M., BERNOULLI, D., FÜGENSCHUH, B., MATENCO, L., SCHEFER, S., SCHUSTER, R., TISCHLER, M. \& USTASZEWSKI, K. (2008): The Alpine-Carpathian-Dinaridic orogenic system: correlation and evolution of tectonic units.- Swiss J. Geosci., $101,139-183$.

SCHROLL, A. \& NEUBAUER, F. (2013): Emplacement of an evaporitic mélange nappe in central Northern Calcareous Alps: evidence from the Moosegg klippe (Austria).- Austrian J. Earth Sci., 104/2, 22-46.

SHEPERD, T.J., RANKIN, A.H. \& ALDERTON, D.H.M. (1985): A practical guide to fluid inclusion studies.- Blackie \& Son Ltd., Glasgow, $239 \mathrm{p}$.

SIBLEY, D.F. \& GREGG, J.M. (1987): Classification of dolomite rock textures.- J. Sedim. Petrol., 57, 967-975.

SPÖTL, CH. \& HASENHÜTTL, CH. (1998): Thermal history of the evaporitic Haselgebirge mélange in the Northern Calcareous Alps (Austria).- Geol. Rundschau, 87, 449-460.

ŠIFTAR, D. (1986): Starost evaporita u području Sinj-gornji tok Une.Geol. vjesnik, Zagreb, 39, 55-60.

SPAIĆ, V. (2012): Oil and gas bearingness and structural elements of Adriatic islands and peninsulas (Outer Dinarides) with special review of anhydrite - carbonate Mesozoic complex and diapiric belt.Nafta, 63/1-2, 29-37.

ŠUŠNJARA, A., SAKAČ, K., JELEN, B. \& GABRIĆ, A. (1992): Upper Permian evaporites and associated rocks of Dalmatia and borderline area of Lika and Bosnia.- Geol. Croatica, 45, 95-114.

TIŠLJAR, J. (1992): Origin and depositional environments of the evaporitic and carbonate complex (Upper Permian) from the central part of the Dinarides (Southern Croatia and Westen Bosnia).- Geol. Croatica, 45, 115-126.

TOMLJENOVIĆ, B. (2002): Strukturne karakteristike Medvednice i Samoborskog gorja [Structural characteristics of the Mt. Medvednica and the Samoborsko gorje Mt. - in Croatian with an English abstract].- Unpublished PhD Thesis, Faculty of Mining, Geology and Petroleum Engineering, University of Zagreb, 208 p.

VLAHOVIĆ, I., TIŠLJAR, J., VELIC, I. \& MATIČEC, D. (2005): Evolution of the Adriatic Carbonate Platform: Palaeogeography, Main Events and Depositional Dynamics.- Palaeo., Palaeo., Palaeo., 220/3-4, 333-360.

WARREN, J. (1999): Evaporites: their evolution and economics.- Blackwell Science, Oxford, UK, 438 p.

WARREN, J. (2000): Dolomite: occurrence, evolution and economically important associations.- Earth-Sci. Rev., 52, 1-81.

WARREN, J. (2006): Evaporites: sediments, resources and hydrocarbons. - ISBN 3-540-26011-0 Springer Berlin Heidelberg New York, 1041.

YAMAMOTO, H. \& KENNEDY, G.C. (1969): Stability relations in the system $\mathrm{CaSO}_{4}-\mathrm{H}_{2} \mathrm{O}$ at high temperatures and pressures.- Am. J. Sci., 267A, 550-557.

ZIEGENBALG, S.B., BRUNNER, B., ROUCHY, J.M., BIRGEL, D., PIERRE, C., BÖTTCHER, M.E., CARUSO, A., IMMENHAUSER, A. \& PECKMANN, J. (2010): Formation of secondary carbonates and native sulphur in sulphate-rich Messinian strata, Sicily.Sedim. Geol., 227, 37-50. 